\title{
Occurrence and behaviour of uranium and thorium in soil and water
}

\author{
K. Harmsen*1 and F. A. M. de Haan² \\ 1 National Institute for Water Supply (RID), Leidschendam, the Netherlands \\ 2 Department of Soils and Fertilizers, Agricultural State University, Wageningen, \\ the Netherlands
}

Accepted: 26 February 1980

Key words: natural radioactivity, chemical equilibria, adsorption, uranyl complexes, thorium complexes

\section{Summary}

Natural contents of uranium (U) and thorium (Th) in igneous rocks are in the range $0.1-5$ and $1-20 \mathrm{mg} / \mathrm{kg}$ respectively, depending on the type of rock. Felsic rocks, such as granite, usually contain more $\mathrm{U}$ and $\mathrm{Th}$ than mafic rocks, such as basalt and dunite.

Uranium contents in average soils are in the range of $1-4 \mathrm{mg} / \mathrm{kg}$, and thorium contents in the range of $2-12 \mathrm{mg} / \mathrm{kg}$. Contents of $U$ and $\mathrm{Th}$ in mineral soils increase with clay content, due to adsorption at the surface of clay minerals and to the higher $U$ and $T h$ contents of minerals in the clay fraction relative to contents in coarser soil constituents.

Under oxidizing conditions uranium occurs in the soil solution at low $\mathrm{pH}$ as the uranyl ion, $\mathrm{OU}_{2}{ }^{2+}$, or as hydrolysis products of this ion. At higher $\mathrm{pH}$ the uranyl ion may form complexes with carbonate ions. These complexes may be relatively mobile in soils and ground water, because of their negative charge.

Thorium occurs in the soil solution at low $\mathrm{pH}$ as the thorium ion, $\mathrm{Th}^{4+}$, or its hydrolysis products. Above $\mathrm{pH} 4$ the major species in solution will be $\mathrm{Th}(\mathrm{OH})_{2}{ }^{2+}$. However, at high $\mathrm{pH}$ thorium would be virtually absent in soil solutions, due to the strongly decreasing solubility of thorium oxide, $\mathrm{ThO}_{2}$, with increasing $\mathrm{pH}$.

Organic acids, such as acetic acid and oxalic acid, may form soluble complexes with $U$ and $T h$, and thus increase the solubility of these elements in soils.

The mobility of $U$ and $T h$ in soils will generally be limited, due to the formation of sparingly soluble precipitates (e.g. phosphates, oxides) and adsorption to the soil

* Present address: The International Center for Agricultural Research in the Dry Areas ICARDA, P.O. Box 5466, Aleppo, Syria. 
matrix. Contents of $U$ and $T h$ in natural waters are in the range 0.1 to $10 \mu \mathrm{g} / 1$. In ground water higher contents may occur under conditions of low $\mathrm{pH}$, low adsorption capacity and the absence of ionic species that form precipitates with $U$ or $T h$.

\section{Introduction}

Thorium (Th) and uranium (U) are sources of nuclear power. Much of the internal heat of the earth is attributed to nuclear transformation of uranium and thorium. Thorium is about three times as abundant in the earth's crust as uranium. Natural uranium, slightly enriched with $\mathrm{U}-235$, is used to fuel nuclear power reactors for the generation of electricity. Thorium is not yet used on a large scale as a nuclear fuel, but might be so in future, when thorium cycle converter reactors would be in operation. There is probably more energy available for use from thorium in the minerals of the earth's crust than from both uranium and fossil fuels (Weast, 1973). Although the use of nuclear fuel to generate electrical power is subject to discussion, it may be expected that the world-wide capacity of nuclear power plants will increase considerably during the next few decades.

Not only nuclear power plants, but also atmospheric releases from coal-fired power plants could result in uranium and thorium enrichment of surrounding soils. For example, uranium contents in fly ash $(30 \mathrm{mg} / \mathrm{kg})$ were enriched with respect to slag $(15 \mathrm{mg} / \mathrm{kg})$, and higher than in average soil $(1-4 \mathrm{mg} / \mathrm{kg})$. The concentration of thorium in slag $(15 \mathrm{mg} / \mathrm{kg})$ and fly ash $(20 \mathrm{mg} / \mathrm{kg})$ were slightly higher than in average soil (2-12 $\mathrm{mg} / \mathrm{kg}$ ) (Klein et al., 1975).

A wide variety of industrial products contain radioactive nuclides that have been deliberately incorporated to satisfy a specific purpose.

The main uses of uranium in consumer products are either as a pigment or in applications making use of its high density. So-called 'depleted' uranium, i.e. natural uranium with a U-235 content lowered to less than $0.2 \%$, is used in inertial guiding devices, as shielding material, in photographic applications and in analytical chemistry. For example, porcelains used in dentistry, optical lenses and alloys may contain significant amounts of uranium. Compounds containing uranium are also used in the chemical industry as catalysts.

Thorium has been used principally in the preparation of incandescent mantles (Welsbach mantles) in electronic and electrical devices, such as gas-discharge lamps and vacuum tubes. Thorium is further used in ceramics and glassware. Thorium is an important alloying element in magnesium, and it is used tot coat tungsten wire in electronic equipment. Glasses containing thorium find application in lenses for cameras and scientific instruments. Thorium dioxide is a catalyst in several chemical processes.

The increasing uranium and thorium requirements of the nuclear industry, the use of these elements in consumer products and as catalysts in industrial processes, does create a waste disposal problem. Therefore, the behaviour of uranium and thorium in soil-water systems might become of increasing importance in the near future. The present review summarizes some data on the occurrence of uranium and thorium in the earth's crust and natural waters. The behaviour of uranium and 
thorium in soil-water systems is discussed, with thermodynamic data obtained from the literature.

\section{Some definitions and physical data}

Thorium, atomic number 90 , and uranium, atomic number 92 , occur only in radioactive form. The number of disintegrations (or: nuclear transformations) occurring in a given quantity of radioactive material per unit time is referred to as the activity of that material. The special unit of activity is the curie (Ci). One curie equals $3.7 \times 10^{10}$ disintegrations per second (abbr.: dps). The specific activity of a given nuclide or compound is the total activity occurring per unit mass of that nuclide or compound, expressed in $\mathrm{Ci} / \mathrm{kg}$.

Natural thorium (Th-nat) is a mixture of $232 \mathrm{Th}$ and $225 \mathrm{Th}$ in proportions that produce an equal number of disintegrations per second. According to the radiological definiton, $1 \mathrm{Ci}$ of Th-nat corresponds to a quantity of $232 \mathrm{Th}$ and of $228 \mathrm{Th}$ that each produce $3.7 \times 1010 \mathrm{dps}$. Thorium-232 is a natural radionuclide that, because of its extremely long half-life, has remained at the head of one of the major series of natural radioisotopes. Thorium-228 is a daughter (i.e. decay product) of thorium-232. It takes about 20 years' for ${ }^{232}$ Th to reach equilibrium with its daughter products. The $232 \mathrm{Th}$ decay chain ends with lead-208, which is stable.

Natural uranium (U-nat) is a mixture of three natural radionuclides in the proportions found in nature (see Table 1). The percentage by weight of $235 \mathrm{U}$ in natural uranium varies by as much as $0.1 \%$, depending on the source. According to the radiological definition, $1 \mathrm{Ci}$ of $\mathrm{U}$-nat corresponds to a quantity of $238 \mathrm{U}$ and of ${ }^{234} \mathrm{U}$ that each yield $3.7 \times 10^{10} \mathrm{dps}$, plus a quantity of $235 \mathrm{U}$ that yields $1.7 \times 10^{9}$ dps. Because of their extremely long half-lives, several isotopes of uranium are the starting point of major series of natural radionuclides. Uranium-238 is at the head of the uranium-radium series, which ends with the stable lead-206. Its daughter elements include $234 \mathrm{U}$. Uranium-235 is at the head of the uranium-actinium series, which ends with the stable lead-207.

Table 1 summarizes some physical data and maximum permissible concentrations in water $\left(\mathrm{MPC}_{\mathrm{w}}\right)$ for uranium and thorium. The average abundances of the

Table 1. Some physical data and $\mathrm{MPC}_{\mathrm{W}}$ values for $\mathrm{U}$ and $\mathrm{Th}$.

\begin{tabular}{|c|c|c|c|c|c|}
\hline & \multirow{2}{*}{$\begin{array}{l}\text { Abundance } \\
(\% \cdot w / w)\end{array}$} & \multirow{2}{*}{$\begin{array}{l}\text { Half life } \\
\text { (years) }\end{array}$} & \multirow{2}{*}{$\begin{array}{l}\text { Specific } \\
\text { activity } \\
(\mu \mathrm{Ci} / \mathrm{g})\end{array}$} & \multicolumn{2}{|l|}{$\mathrm{MPC}_{\mathrm{wV}}{ }^{168}$} \\
\hline & & & & $(\mu \mathrm{Ci} / \mathrm{ml})$ & $(\mathrm{mg} / \mathrm{l})$ \\
\hline Th-232 & 100 & $1.40 \times 10^{10}$ & 0.11 & $2 \times 10^{-5}$ & $1.8 \times 10^{2}$ \\
\hline Th-228 & $1.37 \times 10^{-8}$ & 1.913 & $8.3 \times 10^{8}$ & $7 \times 10^{-5}$ & $9 \times 10^{-8}$ \\
\hline Th-nat & $(100)$ & - & $(0.11)$ & $1 \times 10^{-5}$ & $0.9 \times 10^{2}$ \\
\hline U-238 & 99.2746 & $4.468 \times 10^{9}$ & 0.34 & $6 \times 10^{-6}$ & 18 \\
\hline U-235 & 0.720 & $7.04 \times 10^{8}$ & 2.2 & $4 \times 10^{-5}$ & 18 \\
\hline U-234 & 0.0054 & $2.44 \times 10^{5}$ & $6.3 \times 10^{3}$ & $4 \times 10^{-5}$ & $6 \times 10^{-3}$ \\
\hline U-nat & $(100)$ & - & $(0.34)$ & $6 \times 10^{-6}$ & 18 \\
\hline
\end{tabular}


nuclides in naturally occurring $U$ and $T h$, and the half-lives of the nuclides are taken from the 'Chart of the nuclides' (Walker et al., 1977).

The average abundance of $228 \mathrm{Th}$ in Th-nat is calculated from the half-life of $228 \mathrm{Th}$ and the radiological definition of Th-nat. The relation:

$$
\mathrm{dN} / \mathrm{dt}=-\mathrm{kN}
$$

expresses that the decrease in the number of radioactive nuclei, i.e. the number of disintegrations, per unit time $(\mathrm{dN} / \mathrm{dt})$ is proportional $(\mathrm{k})$ to the number of radioactive nuclei present at time $t(N)$. From this relation it follows that the specific activity of a nuclide may be calculated from:

$$
\text { spec. act. }=\left(\ln 2 / \mathrm{T}_{2}^{1}\right) \times\left(\mathrm{N}_{\mathrm{Av}} / \text { at.wt. }\right) \times\left(10^{6 / 3.7} \times 10^{10}\right) \mu \mathrm{Ci} / \mathrm{g},
$$

where $T_{\frac{1}{2}}$ is the half-life (in seconds) and at.wt. the atomic weight (g) of the nuclide considered, $\ln 2$ is the natural logarithm of 2 , and $\mathrm{N}_{\mathrm{Av}}$ is the Avogadro constant. The specific activities of Th-nat and U-nat cannot be calculated in this way, but they can be derived from the specific activities of the nuclides that make up the natural elements. For example, $1 \mu \mathrm{Ci}$ U-nat corresponds to $1 \mu \mathrm{Ci} 238 \mathrm{U}(=2.94 \mathrm{~g})$ plus $1 \mu \mathrm{Ci}{ }^{234} \mathrm{U}\left(=1.6 \times 10^{-4} \mathrm{~g}\right)$ plus $0.046 \mu \mathrm{Ci} 235 \mathrm{U}(=0.02 \mathrm{~g})$, such that $1 \mu \mathrm{Ci}$ $\mathrm{U}$-nat corresponds to a mass of $2.96 \mathrm{~g}$, and thus the specific activity equals 0.34 $\mu \mathrm{Ci} / \mathrm{g}$. It may be noted, however, that on the basis of the abundance of the nuclides in natural uranium a different result would be obtained. Natural uranium would then have a specific activity of: $0.992746 \times 0.34+0.72 \times 10^{-2} \times 2.2+0.54 \times$ $10^{-4} \times 6.3 \times 10^{3}=0.69 \mu \mathrm{Ci} / \mathrm{g}$. Since the $\mathrm{MPC}_{\mathrm{w}}$ values in Table 1 are based on the radiological definitions of $\mathrm{Th}$-nat and $\mathrm{U}-\mathrm{nat}$, only the specific activities derived from those definitions are given in Table 1.

The maximum permissible concentrations of radionuclides in water, $\mathrm{MPC}_{\mathrm{w}}{ }^{168}$, given in Table 1, apply to the nuclides in soluble form, and are based on occupational, continuous exposure (168 hours per week). Values for non-occupational exposure are a factor 10 lower. The $\mathrm{MPC}_{\mathrm{w}}$ values are based on the recommendations of the International Commission on Radiological Protection (ICRP). Values for Th are based on radiological toxicity (ICRP, 1959) and for $U$ on chemical toxicity (ICRP, 1964). From the $\mathrm{MPC}_{\mathrm{w}}$ values in Table 1 it may be derived that for U-nat a concentration of $8 \times 10^{-6} \mathrm{~mol} / 1$ would be the maximum permissible concentration for soluble compounds and for continuous, non-occupational exposure, whereas for Th-nat this value is about 5 times higher: $4 \times 10^{-5} \mathrm{~mol} / 1$.

\section{Natural occurrence of uranium and thorium}

Occurrence in the earth's crust

Table 2 summarizes the occurrence of $U$ and Th in the earth's crust. Both elements appear to be more abundant in felsic igneous rock (granite) than in mafic materials. Among the sedimentary rocks, shales tend to have higher $U$ and $T h$ contents than sandstone and limestone. This probably reflects the higher $U$ and Th contents of the minerals in the clay fraction, relative to minerals in coarser fractions or to carbonates. Therefore, it may be expected that in uncontaminated mineral soils $U$ 
Table 2. Abundance of uranium and thorium in the earth's crust.

\begin{tabular}{|c|c|c|c|}
\hline & $\begin{array}{l}\text { Uranium } \\
(\mu \mathrm{g} / \mathrm{g})\end{array}$ & $\begin{array}{l}\text { Thorium } \\
(\mu \mathrm{g} / \mathrm{g})\end{array}$ & Reference $^{1}$ \\
\hline \multicolumn{4}{|l|}{ Lithosphere } \\
\hline \multicolumn{4}{|l|}{ Igneous Rock } \\
\hline felsic granitic & $3-5$ & $10-20$ & $1,2,4,5$ \\
\hline intermediate & $2-3$ & $7-10$ & $1,2,5$ \\
\hline magic, basaltic & 1 & $3-6$ & $1,2,4,5$ \\
\hline \multicolumn{4}{|l|}{ Sedimentary Rock } \\
\hline shales & $3-4$ & $11-12$ & $1,4,5$ \\
\hline sandstone & $0.5-1.5$ & $2-3$ & 1,4 \\
\hline limestone, carbonate & $2-2.5$ & $1.5-2$ & 1,4 \\
\hline rock phosphate & $30-300$ & $5-25$ & 3 \\
\hline \multicolumn{4}{|l|}{ Soil } \\
\hline average & 1-2 & 6 & $1,4,6$ \\
\hline typical range & $1-4$ & $2-12$ & 1 \\
\hline
\end{tabular}

1 Generalized from: Unscear, 1977 (1); Osburn, 1975 (2); Menzel, 1968 (3); Klement, 1965 (4); Vinogradov, 1959 (5); Baranov \& Morozova, 1971 (6); and Mitchell, 1955 (7).

and Th mainly occur in the clay fraction of the soils. In soils contaminated by $U$ or Th this tendency might even be more pronounced, due to the higher adsorption capacity of the minerals in the clay fraction relative to coarser fractions.

In the lithosphere the $\mathrm{Th} / \mathrm{U}$ ratio is close to 3 (Klement, 1965), whereas in soils this ratio ranges from 2.5-5 (Unscear, 1977; Vinogradov, 1959; Talibudeen, 1964; Baranov \& Morozova, 1971). Deviating $\mathrm{Th} / \mathrm{U}$ ratios in soils form an indication for enrichment or leaching of one of the two elements.

Phosphate deposits usually contain relatively high concentrations of the naturally occurring radionuclides of the $238 \mathrm{U}$ series. Uranium is found in phosphate rock and in monazite sands, and can be recovered commercially from these sources. The dispersal of mining wastes in the environment, and the use of phosphate fertilizers in agriculture are possible sources of uranium (and thorium) enrichment in soils.

The average concentrations of $U$ and $T h$ in phosphate fertilizers are of the same order as in rock phosphate (see Table 2). It follows that the Th contents of phosphate fertilizers are of the same order as in average soils, or slightly higher, whereas $\mathrm{U}$ contents are a factor 100 higher. If $100 \mathrm{~kg} \mathrm{P}_{2} \mathrm{O}_{5}$, containing $100 \mathrm{mg} \mathrm{U} / \mathrm{kg} \mathrm{P}_{2} \mathrm{O}_{5}$, is applied per hectare per year, this would result in an addition of $10 \mathrm{~g} \mathrm{U}$ per ha per year. If all $\mathrm{U}$ would accumulate in the top $20 \mathrm{~cm}$ of the soil, this would result in a yearly uranium enrichment of $3 \mu \mathrm{g} \mathrm{U} / \mathrm{kg}$ soil (bulk density $1.5 \mathrm{~g} / \mathrm{cm}^{3}$ ). Hence it would take 3 centuries of phosphate fertilization to increase the uranium content of the soil by $1 \mathrm{mg} / \mathrm{kg}$.

\section{Occurrence in natural waters}

The uranium content of natural waters generally is in the range $0.1-10 \mu \mathrm{g} / 1$ (Brits $\&$ Smit, 1977). From the data in Table 3 it follows that higher contents may occur, 
Table 3. Occurrence of uranium in natural waters.

\begin{tabular}{|c|c|c|}
\hline Type of water; location & Range $(\mu \mathrm{g} / 1)$ & Reference \\
\hline \multicolumn{3}{|l|}{ Ground water } \\
\hline West-Australia & $40-200$ & Deutscher \& Mann (1977) \\
\hline Darmstadt, FRG & $3.4-12.3$ & Burba et al. (1978) \\
\hline Kansas, USA & $6-23$ & Hathaway \& James (1975) \\
\hline South-Africa & $7.4-8.5$ & Brits \& Smit (1977) \\
\hline USA & $<0.1-120^{1}$ & Scott \& Barker (1962) \\
\hline Helsinki, Finl. & $10-14870^{2}$ & Kahlos \& Asikainen (1973) \\
\hline \multicolumn{3}{|l|}{ Surface water } \\
\hline Austria & $0.1-5^{3}$ & Korkisch \& Gödl (1974) \\
\hline Odenwald, FRG & $0.4-12.0^{4}$ & Burba et al. (1978) \\
\hline Colorado, USA & $0.08-5.27$ & Fleischer \& Delany (1976) \\
\hline Alaska, USA & $0.02-1.6$ & Gladney et al. (1976) \\
\hline New Mexico, USA & $2.0-24$ & Gladney et al. (1976) \\
\hline Netherlands & $0.65-0.89^{5}$ & Van der Sloot $(1976,1979)$ \\
\hline \multicolumn{3}{|l|}{ Sea water } \\
\hline South-Africa & $2.96-3.20$ & Brits \& Smit (1977) \\
\hline Drake Pass., Jap. & $2.7-3.5$ & Sugimura et al. (1964) \\
\hline Netherlands & $2.64-3.37$ & Van der Sloot (1976) \\
\hline World average & 3 & Goldberg (1975) \\
\hline
\end{tabular}

1 Median values of 509 samples devided over 10 geotectic regions were in the range: 02-2.2 $\mu \mathrm{g} / \mathrm{l}$.

2 The distribution of the samples (33) over 4 classes of uranium concentrations was as follows (concentrations in $\mathrm{mg} / 1$ ): $<0.1(17), 0.1-1.0(8), 1.0-10(7),>10(1)$.

3 Most of the samples (more than 100) were in the range 0.1-1.5 $\mu \mathrm{g} / 1$, only 16 samples were in the range $1-5 \mu \mathrm{g} / 1$.

${ }^{4}$ Rhine: $1.7 \mu \mathrm{g} / 1$; Neckar: $1.5 \mu \mathrm{g} / 1$; Main: $1.8 \mu \mathrm{g} / 1$.

5 Rhine.

in particular in ground water. The available data suggest that the uranium contents of surface waters vary within rather narrow limits, possibly as a result of adsorption to bottom sediments or due to the formation of precipitates (e.g. phosphates). Unlike in surface waters, extreme conditions may well occur in ground water. For example, the high uranium contents in ground water of Helsinki (Kahlos \& Asikainen, 1973) could be due to the presence of uranium ores in the granitic subsoil, combined with a low adsorption capacity of the surrounding rock materials, a low $\mathrm{pH}$ and the absence of anions in the ground water that may form precipitates with uranium ions.

Comparatively little information seems to be available with respect to thorium in natural waters. From the data in Table 4 and from the expected chemical behaviour of thorium in aqueous solutions, it may be expected that thorium contents of natural waters are in the same range as uranium contents $(0.1-10 \mu \mathrm{g} / \mathrm{l})$ or slightly lower. The thorium content in sea water is probably low due to the high $\mathrm{pH}(\approx 8)$ and the absence of appreciable amounts of organic complexing agents in sea water. 
Table 4. Occurrence of thorium in natural waters.

$\begin{array}{lll}\text { Type of water; location } & \text { Range }(\mu \mathrm{g} / \mathrm{l}) & \text { Reference } \\ \begin{array}{l}\text { Ground water } \\ \text { Nussdorf, Austria }\end{array} & 0.4-0.5 & \text { Korkisch \& Dimitriades (1973) } \\ \text { Austria } & 1.24-2.90^{1} & \text { Korkisch \& Dimitriades (1973) } \\ \begin{array}{l}\text { Surface water } \\ \text { Austria }\end{array} & 1.24-2.90^{1} & \text { Korkisch \& Dimitriades (1973) } \\ \begin{array}{l}\text { Sea water } \\ \text { World average }\end{array} & 0.05 & \text { Goldberg (1975) }\end{array}$

${ }^{1}$ No significant differences between ground water and surface water (57 samples).

Moffet \& Tellier (1978) investigated the leaching of $U$, Th and other radioactive nuclides from uranium tailings in an abandoned mining area near Elliot Lake, Canada. They concluded that about $95 \%$ of the estimated original thorium content $(170 \mathrm{mg} / \mathrm{kg})$ and about $50 \%$ of the uranium content $(36 \mathrm{mg} / \mathrm{kg})$ of the uranium tailings surface had leached out within 20 years. The $\mathrm{pH}$ of the shallow ground water varied with location. The acidity of the ground water was directly related to the weathering of pyrite in the surface layers of the tailings. Uranium concentrations ranged from $0.05-0.50 \mathrm{mg} / 1$ at high $\mathrm{pH}$ and from $2-40 \mathrm{mg} / 1$ at low $\mathrm{pH}$. Thorium was virtually absent in water samples with a high $\mathrm{pH}$, whereas at low $\mathrm{pH}$ concentrations up to $38 \mathrm{mg} / \mathrm{l}$ were recorded. These data show that under extreme conditions (e.g. uranium tailings, low $\mathrm{pH}$ ) high contents of $\mathrm{U}$ and $\mathrm{Th}$ may occur in natural waters.

\section{Chemical equilibria}

\section{Solubility relationships in soils}

The solubility of uranium and thorium in soil largely determines their mobility in the environment and their availability to plants, and thus plays a major role in assessing the environmental hazard posed by the occurrence of uranium and thorium in soils. The solubility of $\mathrm{U}$ and $\mathrm{Th}$ in soils depends on $\mathrm{pH}$, redox potential, texture and mineral composition of the solid phase, concentrations of inorganic compounds in the soil solution, amount and type of organic compounds in soil and the soil solution, competitive interactions between heavy metals, soil temperature, moisture content and microbial activity.

Transport of $U$ and Th in soil-water systems occurs mainly in dissolved or suspended form, by diffusion or mass flow. Processes that may play a role in the removal of $U$ and $T h$ from the soil solution include incorporation in biological systems coagulation of suspended matter, precipitation or coprecipitation, adsorption, and solid state diffusion. Adsorption of free metal ions, hydrolysis products or complexed species may be caused by electrostatic attraction, London-van der Waals interactions, hydrogen bonding, coordinate bonding or chemical bonding (Harmsen, 1977). 
In the following sections the attention will be focussed on the influence of $\mathrm{pH}$ and redox potential on the solubility of oxides of $U$ and $T h$, on the role played by hydrolysis, and on complex formation with carbonate species and some other ligands. It has to be emphasized, however, that solid phases only provide an ultimate control over the activities of their constituent ions (Lindsay, 1972). Processes such as adsorption of complexed and uncomplexed species may be of more importance under a variety of conditions. Also, the kinetics of precipitation and dissolution are not considered in the present paper, although they may be of considerable importance. Some minerals attain equilibrium within hours, others require years, or may never reach equilibrium. Many solid phases in soils occur in different particle sizes and in different forms, ranging from amorphous to crystalline, and differ in composition (e.g. lattice substitutions) and in the degree of hydration. Therefore the true values of the thermodynamic constants of solid phases in soils may differ significantly from those given in the literature, which usually pertain to pure crystalline phases. Finally it may be noted that solubility products are based on the activities of uncomplexed ionic species in solution. Total concentrations of $U$ and $T h$ in solution will be higher, due to the presence of complexed species, including hydrolysis products, and the existence of activity coefficients smaller than unity.

\section{Solubility of oxides}

The oxides of uranium are very complex: different oxidation states, crystalline modifications and hydration states occur simultaneously, and stoichiometric formulas must be considered as ideal compositions (Cotton \& Wilkinson, 1972). Therefore the values of the thermodynamic constants are difficult to assess, and also the solubilities differ markedly. For example, $\mathrm{UO}_{3}$ is readily soluble, whereas the solubility of $\mathrm{UO}_{3} \cdot \mathrm{H}_{2} \mathrm{O}$ is rather poor. The activity of $\mathrm{UO}_{2}{ }^{2+}$ in equilibrium with $\mathrm{UO}_{3}$ follows from the relationship:

$$
\log \left(\mathrm{UO}_{2}{ }^{2+}\right)=14.3-2 \mathrm{pH}
$$

where parentheses denote the activity of the ionic species in solution, and the activity of $\mathrm{UO}_{2}{ }^{2+}$ in equilibrium with $\mathrm{UO}_{3} \cdot \mathrm{H}_{2} \mathrm{O}$ follows from:

$$
\log \left(\mathrm{UO}_{2}{ }^{2+}\right)=5.2-2 \mathrm{pH}
$$

(averaged from: Robie et al., 1978; Pourbaix, 1963; Garrels \& Christ, 1965; Smith \& Martell, 1976). Hence the predicted activities of $\mathrm{UO}_{2}{ }^{2+}$ differ a factor $10^{9}$, aprpoximately, and $\mathrm{UO}_{3}$ would be unstable in soils: it would transform to $\mathrm{UO}_{3} \cdot \mathrm{H}_{2} \mathrm{O}$, or dissolve and $\mathrm{UO}_{2}{ }^{2+}$ ions would then be adsorbed or form precipitates with other ionic species in solution.

In Figs 1, 2, 4 and 5, it is assumed that $\mathrm{UO}_{3} \cdot \mathrm{H}_{2} \mathrm{O}$ controls the aqueous activity of $\mathrm{UO}_{2}{ }^{2+}$ in soils. It has to be emphasized that uranium concentrations in soil solution may be lower than those calculated on the basis of the solubility product of $\mathrm{UO}_{3} \cdot \mathrm{H}_{2} \mathrm{O}$ at a given $\mathrm{pH}$, as a result of adsorption, occlusion in $\mathrm{Fe}$ or $\mathrm{Mn}$ oxides, solid state diffusion, or precipitation, e.g. as phosphates. However, if the activity of $\mathrm{UO}_{2}{ }^{2+}$ in soil solution would rise above the equilibrium value predicted 
by Eq. 2, $\mathrm{UO}_{3} \cdot \mathrm{H}_{2} \mathrm{O}$ would precipitate from solution. Hence, uranium oxides do provide an ultimate control over the solubility of uranium in soils. Concentrations of total uranium in soil solution may be higher, however, than calculated activities, due to activity corrections and complex formation, including hydrolysis.

The activity of $\mathrm{Th}^{4^{+}}$in aqueous solution in equilibrium with thorium dioxide may be estimated from the relationship:

$$
\log \left(\mathrm{Th}^{++}\right)=7-4 \mathrm{pH}
$$

(averaged from Robie et al., 1978; Garrels \& Christ, 1965; Smith \& Martell, 1976). Hence, $\mathrm{ThO}_{2}$ is rather insoluble, comparable with for example $\mathrm{Fe}_{2} \mathrm{O}_{3}$ (hematite) under oxidizing conditions.

\section{Redox equilibria}

Under oxidizing conditions uranium occurs in the hexavalent oxidation state. In aqueous solutions the uranyl ion, $\mathrm{UO}_{2}{ }^{2+}$, which behaves as a divalent heavy metal ion, is formed. Under strongly reducing conditions uranium occurs in the tetravalent oxidation state. In aqueous solutions the major species is then the $\mathrm{UOH}^{3+}$ ion. The transition from the hexavalent to the tetravalent oxidation state in aqueous solution may thus be expressed by the following redox reaction:

$$
\mathrm{UO}_{2}{ }^{2+}+2 \mathrm{e}^{-}+3 \mathrm{H}^{+} \rightleftarrows \mathrm{UOH}^{3+}+\mathrm{H}_{2} \mathrm{O}
$$

Hence, under equilibrium conditions the following relationship would hold:

$$
\log \mathrm{K}^{\circ}=\log \left\{\left(\mathrm{UOH}^{3+}\right) /\left(\mathrm{UO}_{2}{ }^{2+}\right)\right\}+2 \mathrm{pe}+3 \mathrm{pH}
$$

where $\mathrm{K}^{\circ}$ denotes the equilibrium constant for reaction (4) and pe is the negative logarithm of the relative electron activity.

Although aqueous solutions do not contain free electrons (or free protons), pe may be used as a measure for the electron activity in aqueous solutions (Stumm \& Morgan, 1970). Oxidizing conditions are characterized by low electron activities (high positive values of pe) and reducing conditions correspond to high electron activities (small positive, or negative values of pe). In this paper the more commonly used redox potental, E, will be used as a measure for the redox conditions of a system. The redox potential is related to pe by:

$$
\mathrm{E}=(2.3 \mathrm{RT} / \mathrm{F}) \mathrm{pe}
$$

where $\mathbf{R}$ is the Gas Constant, $\mathrm{T}$ the absolute temperature $(\mathrm{K})$, and $\mathrm{F}$, the Faraday Constant. The numerical value of the expression $(2.3 \mathrm{RT} / \mathrm{F})$ at $25^{\circ} \mathrm{C}$ equals $0.059 \mathrm{~V}$.

The standard redox potential, $\mathrm{E}^{\circ}$, is related to the equilibrium constant, $\mathrm{K}^{\circ}$, by:

$$
\mathrm{E}^{\circ}=(2.3 \mathrm{RT} / \mathrm{nF}) \log \mathrm{K}^{\circ}
$$

where $\mathbf{n}$ denotes the number of electrons transferred in the redox reaction. Hence, Eq. 5 may be written as:

$$
\mathrm{E}=\mathrm{E}^{\circ}-0.089 \mathrm{pH}+0.030 \log \left\{\left(\mathrm{UO}_{2}{ }^{2+}\right) /\left(\mathrm{UOH}^{3+}\right)\right\}
$$


The $\mathrm{E}^{\circ}$ value in Eq. 8 is about $0.299 \mathrm{~V}$ (Pourbaix, 1963). If the activities of the two uranium species in solution are equal to each other, Eq. 8 reduces to:

$$
\mathrm{E}=0.299-0.089 \mathrm{pH}
$$

This relationship is plotted in Fig. 1 as line 1 . Hence, above the broken line in Fig. 1 the major species in aqueous solution is $\mathrm{UO}_{2}{ }^{2+}$, and below that line this is $\mathrm{UOH}^{3+}$.

The dots and dashes in Fig. 1 indicate the upper and lower limits of the stability of water. Under oxidizing conditions water may be oxidized according to:

$$
2 \mathrm{H}_{2} \mathrm{O} \rightarrow \mathrm{O}_{2}(\mathrm{~g})+4 \mathrm{H}^{+}+4 \mathrm{e}^{-}
$$

where $(\mathrm{g})$ denotes the gas phase. If equilibrium exists between water and oxygen gas, Eq. 10 determines a redox potential according to:

$$
\mathrm{E}=\mathrm{E}^{\circ}-0.059 \mathrm{pH}+0.015 \log \mathrm{P}\left(\mathrm{O}_{2}\right)
$$

where $\mathrm{P}\left(\mathrm{O}_{2}\right)$ denotes the partial oxygen pressure.

The upper limit of water stability may be defined as the equilibrium between water and oxygen gas at 1 atmosphere pressure. Hence, the upper limit of water stability follows from:

$$
\mathrm{E}=1.228-0.059 \mathrm{pH}
$$

This relation is plotted in Fig. 1, line (a). Under reducing conditions water may be reduced according to:

$$
2 \mathrm{H}_{2} \mathrm{O}+2 \mathrm{e}^{-} \rightleftarrows \mathrm{H}_{2}(\mathrm{~g})+2 \mathrm{OH}^{-}
$$

or:

$$
2 \mathrm{H}^{+}+2 \mathrm{e}^{-} \rightleftarrows \mathrm{H}_{2} \text { (g) }
$$

The standard redox potential for this reaction is zero, by convention. The lower

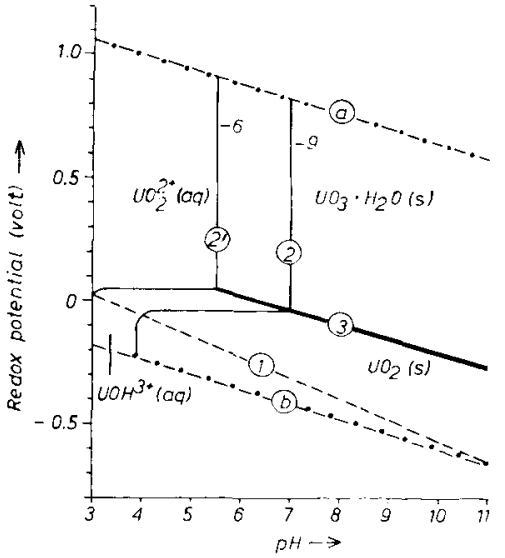

Neth. J. agric. Sci. 28 (1980)
Fig. 1. Redox diagram for the uranium-oxide system. Dissolved (aq) and solid (s) species are indicated. Numbers and letters are explained in the text. 
limit of water stability may be defined as the equilibrium between water and hydrogen gas at 1 atmosphere pressure. Hence, the lower limit of water stability follows from:

$$
\mathrm{E}=0.000-0.059 \mathrm{pH}
$$

This relation is plotted in Fig. 1 as line b.

The thin solid lines in Fig. 1 indicate equilibrium between a solid phase and an aqueous species. Line (2) in Fig. 1 represents equilibrium between $\mathrm{UO}_{2}{ }^{2+}$ and $\mathrm{UO}_{3} \cdot \mathrm{H}_{2} \mathrm{O}$ at high redox potential, at an aqueous concentration of $10^{-9} \mathrm{~mol} / \mathrm{l}$, according to:

$$
\mathrm{UO}_{2}{ }^{2+}+2 \mathrm{H}_{2} \mathrm{O} \rightleftarrows \mathrm{UO}_{3} \cdot \mathrm{H}_{2} \mathrm{O}+2 \mathrm{H}^{+}
$$

which yields the relationship:

$$
\mathrm{pH}=6.99
$$

At lower $\mathrm{E}$, line 2 represents equilibrium between $\mathrm{UO}_{2}{ }^{2+}$ and $\mathrm{UO}_{2}$, according to:

$$
\mathrm{UO}_{2} \rightleftarrows \mathrm{UO}_{2} 2^{+}+2 \mathrm{e}^{-}
$$

which yields the relationship

$$
\mathrm{E}=-0.045
$$

At still lower E, line 2 in Fig. 1 represents equilibrium between $\mathrm{UOH}^{3+}$ and $\mathrm{UO}_{2}$, according to:

$$
\mathrm{UOH}^{3+}+\mathrm{H}_{2} \mathrm{O} \rightleftarrows \mathrm{UO}_{2}+3 \mathrm{H}^{+}
$$

which yields the relationship:

$$
\mathrm{pH}=3.88
$$

For reasons of consistency all $\mathrm{E}^{\circ}$ values in Eqs 16, 18 and 20 are taken from Pourbaix (1963). Line $2^{\prime}$ in Fig. 1 represents the same equilibria as line 2, but for an aqueous activity of uranium ions of $10^{-6} \mathrm{~mol} / \mathrm{l}$.

The thick solid line in Fig. 1, line 3, represents equilibrium between two solid phases according to:

$$
\mathrm{UO}_{2}(\mathrm{~s})+\mathrm{H}_{2} \mathrm{O} \rightleftarrows \mathrm{UO}_{3} \cdot \mathrm{H}_{2} \mathrm{O}(\mathrm{s})+2 \mathrm{H}^{+}+2 \mathrm{e}^{-}
$$

This yields the following relationship for the redox potential:

$$
\mathrm{E}=0.368-0.059 \mathrm{pH}
$$

where it is assumed that the activities of the two solid phases are equal to each other.

It follows from Fig. 1 that $\mathrm{UO}_{2}(\mathrm{~s})$ is less soluble than $\mathrm{UO}_{3} \cdot \mathrm{H}_{2} \mathrm{O}$ under reducing conditions. Therefore, upon lowering the redox potential the solubility of aqueous uranium species would decrease if these oxides were controlling the solubility. Moreover, the trivalent $\mathrm{UOH}^{3+}$ ions would strongly be adsorbed by negatively 
charged surfaces in soils, which would contribute to a decrease of the mobility of uranium in soils upon lowering the redox potential.

Thorium occurs only in the tetravalent oxidation state under $\mathrm{pH}-\mathrm{E}$ conditions occurring in soils. Unlike for $\mathrm{U}^{4+}$, the major species in aqueous solution would here be the second hydrolysis product, $\mathrm{Th}(\mathrm{OH})_{2}{ }^{2+}$ (see also Fig. 3).

\section{Hydrolysis}

The solubility of both uranium oxides and thorium oxides is increased by the formation of hydrolysis products (Cotton \& Wilkinson, 1972) i.e. the amount of uranium in solution at high redox potential in a pure $\mathrm{H}_{2} \mathrm{O}-\mathrm{UO}_{3} \cdot \mathrm{H}_{2} \mathrm{O}$ system would be higher than estimated from Fig. 1, due to the formation of hydrolysis products such as $\mathrm{UO}_{2}(\mathrm{OH})^{+}$and $\left(\mathrm{UO}_{2}\right)_{3}(\mathrm{OH})_{5}{ }^{+}$. The hydrolysis of a heavy metal ion in solution may be described as the transfer of a proton from a water molecule in the inner hydration sheath to a surrounding water molecule. For example, for thorium the first hydrolysis reaction may be written as:

$$
\mathrm{Th}\left(\mathrm{H}_{2} \mathrm{O}\right)_{\mathrm{n}}{ }^{+}+\mathrm{H}_{2} \mathrm{O} \gtrless \mathrm{Th}\left(\mathrm{H}_{2} \mathrm{O}\right)_{\mathrm{n}-1}(\mathrm{OH})^{3^{+}}+\mathrm{H}_{3} \mathrm{O}^{+}
$$

where $\mathrm{n}$ denotes the number of water molecules in the inner hydration sheath, i.e. coordinated with the $\mathrm{Th}^{4+}$ ion.

Eq. 23 may be written alternatively:

$$
\mathrm{Th}^{4+}+\mathrm{H}_{2} \mathrm{O}=\mathrm{ThOH}^{3+}+\mathrm{H}^{+}
$$

where the hydration sheath of $\mathrm{Th}^{4^{+}}$is not considered explicitly. The hydrolysis reaction may also be described as complex formation between a metal ion (e.g. $\mathrm{Th}^{4+}$ and one or more ligands $\left(\mathrm{OH}^{-}\right)$; see for example Smith \& Martell (1976).

Under oxidizing conditions the following reactions involving uranyl ions are of importance:

$$
\begin{aligned}
& \mathrm{UO}_{2}{ }^{2+}+2 \mathrm{H}_{2} \mathrm{O} \rightleftarrows \mathrm{UO}_{3}: \mathrm{H}_{2} \mathrm{O}(\mathrm{s})+2 \mathrm{H}^{+} \\
& \mathrm{UO}_{2}{ }^{2+}+\mathrm{H}_{2} \mathrm{O} \rightleftarrows \mathrm{UO}_{2} \mathrm{OH}^{+}+\mathrm{H}^{+} \\
& 2 \mathrm{UO}_{2}{ }^{2+}+2 \mathrm{H}_{2} \mathrm{O} \rightleftarrows\left(\mathrm{UO}_{2}\right)_{2}(\mathrm{OH})_{2}{ }^{2+}+2 \mathrm{H}^{+} \\
& 3 \mathrm{UO}_{2}{ }^{2+}+5 \mathrm{H}_{2} \mathrm{O} \rightleftarrows\left(\mathrm{UO}_{2}\right)_{3}(\mathrm{OH})_{5}+5 \mathrm{H}^{+}
\end{aligned}
$$

reactions 25 to 28 yield the following set of equilibrium relationships:

$$
\begin{aligned}
& \log \left(\mathrm{UO}_{2}{ }^{2+}\right)=5.6-2 \mathrm{pH} \\
& \log \left(\mathrm{UO}_{2} \mathrm{OH}^{+}\right)=\log \left(\mathrm{UO}_{2}{ }^{2+}\right)+\mathrm{pH}-5.8 \\
& \log \left(\left(\mathrm{UO}_{2}\right)_{2}(\mathrm{OH})_{2}{ }^{2+}\right)=2 \log \left(\mathrm{UO}_{2}{ }^{2+}\right)+2 \mathrm{pH}-5.6 \\
& \log \left(\left(\mathrm{UO}_{2}\right)_{3}(\mathrm{OH})_{5}{ }^{+}\right)=3 \log \left(\mathrm{UO}_{2}{ }^{2+}\right)+5 \mathrm{pH}-15.6
\end{aligned}
$$

where all $\log \mathrm{K}^{\circ}$ data are taken from Smith \& Martell (1976), and refer to $25^{\circ} \mathrm{C}$ and zero ionic strength. It follows from Eqs 30 to 32 that the amount of hydrolysis products in solution depends upon both the activity of $\mathrm{UO}_{2}{ }^{2+}$ and $\mathrm{pH}$. Assuming 
that the aqueous activity of $\mathrm{UO}_{2}{ }^{2+}$ is uniquely determined by the solubility of $\mathrm{UO}_{3} \cdot \mathrm{H}_{2} \mathrm{O}$, according to Eq. 29, it follows that Eqs 30 to 32 simplify to:

$$
\begin{aligned}
& \log \left(\mathrm{UO}_{2} \mathrm{OH}^{+}\right)=-0.2-\mathrm{pH} \\
& \log \left(\left(\mathrm{UO}_{2}\right)_{2}(\mathrm{OH})_{2}{ }^{2+}\right)=5.6-2 \mathrm{pH} \\
& \log \left(\left(\mathrm{UO}_{2}\right)_{3}(\mathrm{OH})_{5}{ }^{+}\right)=1.2-\mathrm{pH}
\end{aligned}
$$

Eqs 29 and 33 to 35 are plotted in Fig. 2.

It has to be emphasized that uncertainty exists with respect to the exact values of the hydrolysis constants and the solubility of $\mathrm{UO}_{3} \cdot \mathrm{H}_{2} \mathrm{O}$. Therefore, Fig. 2 shows trends rather than exact relationships. It can be seen, however, that hydrolysis contributes significantly to the solubility of uranium in $\mathrm{H}_{2} \mathrm{O}-\mathrm{UO}_{3} \cdot \mathrm{H}_{2} \mathrm{O}$ systems. At pH 5 and higher the major species in solution will be $\left(\mathrm{UO}_{2}\right)_{3}(\mathrm{OH})_{5}{ }^{+}$.

The following reactions are of major importance in determining the solubility of thorium in $\mathrm{H}_{2} \mathrm{O}-\mathrm{ThO}_{2}$ systems:

$$
\begin{aligned}
& \mathrm{Th}^{4^{+}}+2 \mathrm{H}_{2} \mathrm{O} \rightleftarrows \mathrm{ThO}_{2}(\mathrm{~s})+4 \mathrm{H}^{+} \\
& \mathrm{Th}^{4+}+\mathrm{H}_{2} \mathrm{O} \rightleftarrows \mathrm{ThOH}^{3+}+\mathrm{H}^{+} \\
& \mathrm{Th}^{4^{+}}+2 \mathrm{H}_{2} \mathrm{O} \rightleftarrows \mathrm{Th}(\mathrm{OH})_{2}{ }^{2+}+2 \mathrm{H}^{+} \\
& 2 \mathrm{Th}^{4+}+2 \mathrm{H}_{2} \mathrm{O} \rightleftarrows \mathrm{Th}_{2}(\mathrm{OH})_{2}{ }^{6+}+2 \mathrm{H}^{+}
\end{aligned}
$$

Assuming that the aqueous activity of $\mathrm{Th}^{4+}$ is uniquely determined by $\mathrm{ThO}_{2}(\mathrm{~s})$, according to reaction (36), the following set of equilibrium relationships is obtained:

$$
\begin{aligned}
& \log \left(\mathrm{Th}^{4+}\right)=6.3-4 \mathrm{pH} \\
& \log \left(\mathrm{ThOH}^{3+}\right)=3.1-3 \mathrm{pH} \\
& \log \left(\mathrm{Th}(\mathrm{OH})_{2}{ }^{2+}\right)=-0.6-2 \mathrm{pH} \\
& \log \left(\mathrm{Th}_{2}(\mathrm{OH})_{2}{ }^{6+}\right)=6.5-6 \mathrm{pH}
\end{aligned}
$$

where all $\log \mathrm{K}^{\circ}$ data are taken from Smith \& Martell (1976), and refer to $25^{\circ} \mathrm{C}$

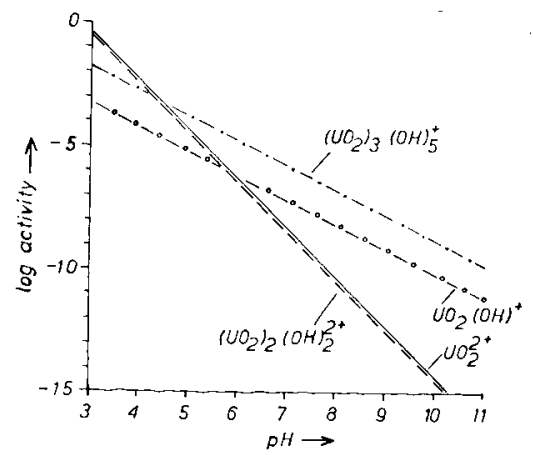

Fig. 2. Activities of $\mathrm{UO}_{2}{ }^{2+}$ and its hydrolysis products in aqueous solution in equilibrium with $\mathrm{UO}_{3} \cdot \mathrm{H}_{2} \mathrm{O}$ under oxidizing conditions. 


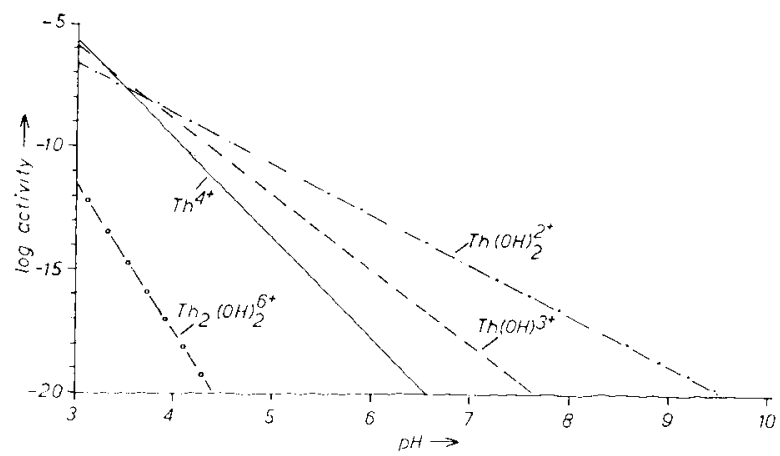

Fig. 3. Activities of $\mathrm{Th}^{4+}$ and its hydrolysis products in aqueous solution in equilibrium with $\mathrm{ThO}_{2}$.

and zero ionic strength. The relationships 40 to 43 are plotted in Fig. 3. It follows from Fig. 3 that at $\mathrm{pH} 4$ and higher $\mathrm{Th}(\mathrm{OH})_{2}{ }^{2+}$ is the major species in solution.

Figs 2 and 3 show that hydrolysis of aqueous species may increase the solubility of uranium and thorium oxides significantly. Both $\mathrm{U}$ and $\mathrm{Th}$ do form polynuclear hydrolysis products, such as $\left(\mathrm{UO}_{2}\right)_{2}(\mathrm{OH})_{2}{ }^{2+},\left(\mathrm{UO}_{2}\right)_{3}(\mathrm{OH})_{5}^{+},\left(\mathrm{UO}_{2}\right)_{3}(\mathrm{OH})_{4}{ }^{2+}$, $\mathrm{Th}_{2}(\mathrm{OH})_{2}{ }^{6+}, \mathrm{Th}_{4}(\mathrm{OH})_{8}{ }^{++}$, and $\mathrm{Th}_{6}(\mathrm{OH})_{15}{ }^{9+}$. Hydrolysis products of heavy metal ions are often selectively adsorbed at oxide surfaces in soils (James \& Healy, 1972; Harmsen, 1977) and therefore it may be expected that hydrolysis products, in particular the higher charged species, contribute relatively little to the mobility of the metals in soils at near neutral or higher $\mathrm{pH}$.

In general, the formation of polynuclear hydrolysis products, in particular the higher charged species, becomes of importance only at high $\mathrm{pH}$ or high metal ion concentrations in solution. It may be noted, however, that locally occurring higher concentrations, such as close to adsorbing surfaces, and the selective adsorption of hydrolysis products, would favour the formation of hydrolysis products, i.e. adsorption would tend to catalyse the hydrolysis reaction.

\section{Carbonate equilibria}

The formation of uranyl-carbonate complexes may significantly increase the solubility of uranium in natural waters, in particular at $\mathrm{pH} 6$ to 7 or higher, and at high partial $\mathrm{CO}_{2}$ pressures. An important aspect of these uranyl-carbonate complexes is that they have negative charges and therefore it may be expected that they will be rather mobile in soils, which usually have a small capacity, if any, to adsorb anions. Not considering hydrolysis, the following reactions are of importance in the $\mathrm{CO}_{2}-\mathrm{H}_{2} \mathrm{O}-\mathrm{UO}_{3} \cdot \mathrm{H}_{2} \mathrm{O}$ system:

$$
\begin{aligned}
& \mathrm{UO}_{2}{ }^{2+}+2 \mathrm{H}_{2} \mathrm{O} \rightleftarrows \mathrm{UO}_{3} \cdot \mathrm{H}_{2} \mathrm{O}+2 \mathrm{H}^{+} \\
& 2 \mathrm{CO}_{2}(\mathrm{~g})+4 \mathrm{H}_{2} \mathrm{O}+\mathrm{UO}_{2}{ }^{2+} \gtrless \mathrm{UO}_{2}\left(\mathrm{CO}_{3}\right)_{2}\left(\mathrm{H}_{2} \mathrm{O}\right)_{2^{2-}}+4 \mathrm{H}^{+} \\
& 3 \mathrm{CO}_{2}(\mathrm{~g})+3 \mathrm{H}_{2} \mathrm{O}+\mathrm{UO}_{2}{ }^{2+} \rightleftarrows \mathrm{UO}_{2}\left(\mathrm{CO}_{3}\right)_{3}{ }^{4^{-}}+6 \mathrm{H}^{+}
\end{aligned}
$$


Uranyl carbonate, $\mathrm{UO}_{2} \mathrm{CO}_{3}(\mathrm{~s})$, would be too soluble to persist in the presence of $\mathrm{UO}_{3} \cdot \mathrm{H}_{2} \mathrm{O}(\mathrm{s})$. Using thermodynamic data listed by Garrels \& Christ (1965) the following set of equilibrium relationships may be derived from Eqs (44)-(46):

$$
\begin{aligned}
& \log \left(\mathrm{UO}_{2}{ }^{2+}\right)=5.85-2 \mathrm{pH} \\
& \log \left(\mathrm{UO}_{2}\left(\mathrm{CO}_{3}\right)_{2}\left(\mathrm{H}_{2} \mathrm{O}\right)_{2^{2-}}{ }^{2-}=-22.6+4 \mathrm{pH}+\log \left(\mathrm{UO}_{2}{ }^{2+}\right)+\log \mathrm{P}\left(\mathrm{CO}_{2}\right)\right. \\
& \log \left(\mathrm{UO}_{2}\left(\mathrm{CO}_{3}\right)_{3}{ }^{4-}\right)=-37.0+6 \mathrm{pH}+\log \left(\mathrm{UO}_{2}{ }^{2+}\right)+3 \log \mathrm{P}\left(\mathrm{CO}_{2}\right)
\end{aligned}
$$

It follows from Eqs 48 and 49 that the formation of uranyl-carbonate complexes is favoured by high $\mathrm{pH}$, high uranyl ion activities and high partial $\mathrm{CO}_{2}$ pressures. The activities of uranyl and of uranyl-carbonate complexes are plotted in Fig. 4, where it is assumed that the activity of $\mathrm{UO}_{2}{ }^{2+}$ is uniquely determined by the solubility of $\mathrm{UO}_{3} \cdot \mathrm{H}_{2} \mathrm{O}$, according to Eq. 47 . It can be seen that, depending on the partial $\mathrm{CO}_{2}$ pressure, at $\mathrm{pH}$ higher than $6\left(3 \% \mathrm{v} / \mathrm{v} \mathrm{CO}_{2}\right)$ or $7(0.03 \% \mathrm{v} / \mathrm{v}$ $\mathrm{CO}_{2}$ ) uranyl-carbonate complexes are the major species in solution.

The uranium content of sea water may be estimated, assuming that $\mathrm{UO}_{2}\left(\mathrm{CO}_{3}\right)_{2}$ $\left(\mathrm{H}_{2} \mathrm{O}\right)_{2}{ }^{2-}$ is the major species and that equilibrium exists with respect to $\mathrm{UO}_{3} \cdot \mathrm{H}_{2} \mathrm{O}$. For $\mathrm{pH}=8.0$ and $\mathrm{P}_{\mathrm{CO2}}=30.4 \mathrm{~Pa}(=0.3 \mathrm{mbar})$ it follows from Eqs 47 and 48 that $\log \left(\mathrm{UO}_{2}\left(\mathrm{CO}_{3}\right)_{2}\left(\mathrm{H}_{2} \mathrm{O}\right)_{2}{ }^{2-}\right)=-7.8$, which corresponds to $3.7 \mu \mathrm{g} \mathrm{U} / 1$, if the activity coefficient of $\mathrm{UO}_{2}\left(\mathrm{CO}_{3}\right)_{2}\left(\mathrm{H}_{2} \mathrm{O}\right)_{2}{ }^{2-}$ is taken to be unity. Since the latter coefficient will be smaller than unity in sea water (ionic strength 0.7 ), it follows that the actual uranium content of sea water $(3 \mu \mathrm{g} \mathrm{U} / \mathrm{l})$ is slightly overestimated, but the estimated value is still close enough to suggest that indeed $\mathrm{UO}_{2}\left(\mathrm{CO}_{3}\right)_{2}$ $\left(\mathrm{H}_{2} \mathrm{O}\right)_{2}{ }^{2-}$ is the major species in sea water and that $\mathrm{UO}_{3} \cdot \mathrm{H}_{2} \mathrm{O}$ is the solid phase determining uranium solubility in sea water. For comparison, when the thorium content of sea water is estimated in a similar way, assuming that equilibrium exists with respect to $\mathrm{ThO}_{2}$ and that $\mathrm{Th}(\mathrm{OH})_{2}{ }^{2+}$ is the major species in solution, the actual Th content of sea water $\left(5 \times 10^{-8} \mathrm{~g} \mathrm{Th} / \mathrm{l}\right)$ is underestimated by a factor $10^{7}$. This would suggest that sea water is strongly supersaturated with respect to $\mathrm{ThO}_{2}$, or that strong complex formation, possibly including polynuclear hydrolysis products, takes place.

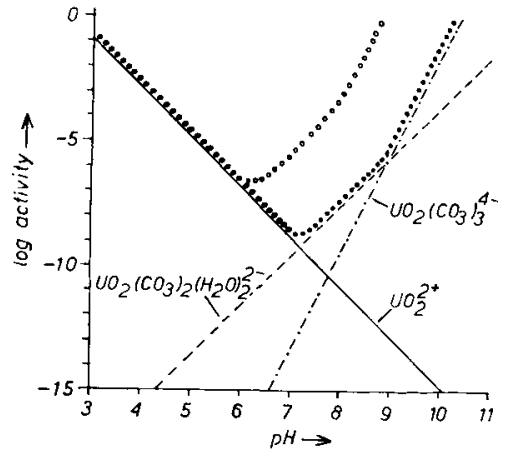

Fig. 4. Activities of uranyl and uranyl-carbonate complexes in aqueous solution for the $\mathrm{CO}_{2}-\mathrm{H}_{2} \mathrm{O}$ $\mathrm{UO}_{3} \cdot \mathrm{H}_{2} \mathrm{O}$ system, not considering hydrolysis of uranyl ions.

Dotted lines indicate the total activity of aqueous uranium species at $0.03 \%(\mathrm{v} / \mathrm{v}) \mathrm{CO}_{2}(\bullet \bullet \bullet \bullet)$ and at $3 \%(\mathrm{v} / \mathrm{v}) \mathrm{CO}_{2}$ (oooo). 


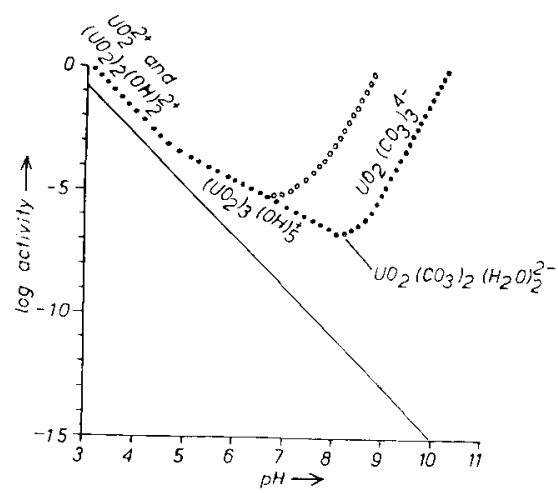

Fig. 5. The total activity of all aqueous uranium species in the $\mathrm{CO}_{2}-\mathrm{H}_{2} \mathrm{O}-\mathrm{UO}_{3} \cdot \mathrm{H}_{2} \mathrm{O}$ system, at two different partial $\mathrm{CO}_{2}$ pressures: $30.4 \mathrm{~Pa}$ $(\bullet \bullet \bullet)$ and $3.04 \mathrm{kPa}($ oooo). The major uranium species in solution are indicated along the dotted curve in the relevant $\mathrm{pH}$ ranges. The solid line indicates the activity of $\mathrm{UO}_{2} 2^{2+}$ in equilibrium with $\mathrm{UO}_{3} \cdot \mathrm{H}_{2} \mathrm{O}$.

The $\mathrm{CO}_{2}-\mathrm{H}_{2} \mathrm{O}-\mathrm{UO}_{3} \cdot \mathrm{H}_{2} \mathrm{O}$ system is not adequately described unless both hydrolysis and complex formation with carbonates are considered. Therefore, in Fig. 5 the total activity of all aqueous uranium species is plotted for the $\mathrm{CO}_{2}-\mathrm{H}_{2} \mathrm{O}-$ $\mathrm{UO}_{3} \cdot \mathrm{H}_{2} \mathrm{O}$ system, considering both hydrolysis and complex formation with carbonates. From Fig. 5 it can be seen that slightly acid ground water ( $\mathrm{pH} 5$ ) may easily contain up to $15 \mathrm{mg} \mathrm{U} / \mathrm{l}$ (see Table 3: ground water of Helsinki). It can also be seen from Fig. 5 that carbonate-rich waters are good solvents for uranium (Vinogradov, 1959; Garrels \& Christ, 1965).

In soils $\mathrm{CO}_{2}$ contents in the gas phase may rise up to $1-10 \%(\mathrm{v} / \mathrm{v})$ or even higher, as a result of biological activity. If the $\mathrm{CO}_{2}$ pressure in the top soil is higher than at depth, uranium could dissolve in the top soil, leach downwards and precipitate again at depth, because of the lower $\mathrm{CO}_{2}$ pressures. This illustrates that upon assessing the solubility and the mobility of uranium in soil the local conditions of $\mathrm{pH}$ and $\mathrm{P}\left(\mathrm{CO}_{2}\right)$ have to be taken into account.

\section{Phosphate equilibria}

The solubility of uranium in soil and natural waters may be limited by the presence of phosphates (Vinogradov, 1959). A considerable part of total dissolved phosphate in soils may be present as organic phosphates. Only part of the phosphate is present as ortho-phosphate: $\mathrm{H}_{3} \mathrm{PO}_{4}, \mathrm{H}_{2} \mathrm{PO}_{4}^{-}, \mathrm{HPO}_{4}{ }^{2-}$ and $\mathrm{PO}_{4}{ }^{3-}$. Ortho-phosphates may form complexes with cations such as $\mathrm{Ca}^{2+}, \mathrm{Mg}^{2+}$ of $\mathrm{Fe}^{3+}$ (Stumm \& Morgan, 1970). The uncomplexed (or free) ortho-phosphates which generally make up only a minor fraction of total dissolved phosphate in soils, may play an important role in determining the solubility of uranium in soils, since both $\mathrm{HPO}_{4}{ }^{2-}$ and $\mathrm{PO}_{4} 3^{3-}$ may form precipitates with $\mathrm{UO}_{2}{ }^{2+}$. In the range of phosphate concentrations commonly encountered in soils, $10^{-5}$ to $10^{-7} \mathrm{~mol} / 1$ (Beek, 1979), $\mathrm{UO}_{2} \mathrm{HPO}_{4}$ is too soluble to persist in the presence of $\mathrm{UO}_{3} \cdot \mathrm{H}_{2} \mathrm{O}$. However, $\left(\mathrm{UO}_{2}\right)_{3}\left(\mathrm{PO}_{4}\right)_{2}$ may play an important role in determining uranium solubility in soils, notably at low $\mathrm{pH}$ and high phosphate concentrations. Fig. 6 shows that $\mathrm{UO}_{3} \cdot \mathrm{H}_{2} \mathrm{O}$ would not persist in a soil at an ortho-phosphate level of $10^{-7} \mathrm{~mol} / \mathrm{l}$ at $\mathrm{pH}$ below 7. At an ortho-phosphate level of $10^{-5} \mathrm{~mol} / 1 \mathrm{UO}_{3} \cdot \mathrm{H}_{2} \mathrm{O}$ would dissolve 


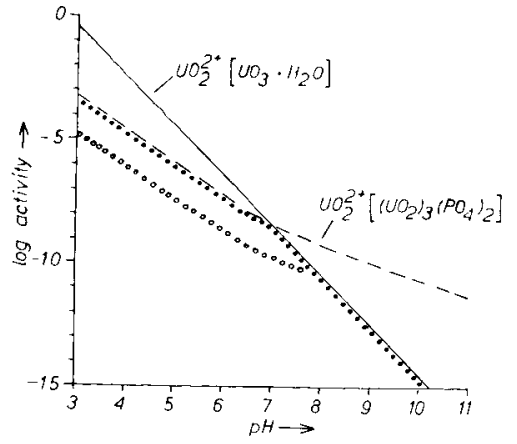

Fig. 6. Activities of $\mathrm{UO}_{2}{ }^{2+}$ in solution in equilibrium with $\mathrm{UO}_{3} \cdot \mathrm{H}_{2} \mathrm{O}$ (solid line) and with $\left(\mathrm{UO}_{2}\right)_{3}\left(\mathrm{PO}_{4}\right)_{2}$ (broken line). The activity of $\mathrm{UO}_{2}{ }^{2+}$ for the $\mathrm{H}_{2} \mathrm{O}-\mathrm{UO}_{2}{ }^{2+}$ ortho $P$ system is plotted for two different ortho-phosphate concentrations: $10^{-\pi}$ $\mathrm{mol} / \mathrm{l}(\bullet \bullet \bullet \bullet)$ and $10^{-5} \mathrm{~mol} / \mathrm{l}(\mathrm{oooo})$.

at $\mathrm{pH}$ values lower than 8 . Hence uranium phosphate would determine $\mathrm{UO}_{2}{ }^{2+}$ activities in solution at $\mathrm{pH}$ below 7 to 8 . At higher $\mathrm{pH}$ values, uranium trioxide would determine $\mathrm{UO}_{2}{ }^{2+}$ solubility and uranium phosphate would dissolve. This is mainly because the $\mathrm{PO}_{4}{ }^{3-}$ activity increases strongly with increasing $\mathrm{pH}$, if the total $\mathrm{P}$ concentration is kept constant. Since phosphates generally occur in soils (fertilizers) and surface waters (detergents), they may play a part in determining the solubility of uranium, in particular under near neutral or slightly acidic conditions.

The effect of hydrolysis and complex formation with carbonates on the solubility of uranium in aqueous solutions containing free ortho-phosphates is shown in Figs 7 and 8. At a low ortho-phosphate concentration $\left(10^{-7} \mathrm{~mol} / 1\right.$; Fig. 7$)$ the total concentration of aqueous uranium in the $\mathrm{pH}$ range of 5 to 9 would be fairly constant between $10^{-6}$ and $10^{-7} \mathrm{~mol} / 1$. The major ionic species in solution between pH 6 and 8.5 would be $\left(\mathrm{UO}_{2}\right)_{3}(\mathrm{OH})_{5}{ }^{+}$. At higher ortho-phosphate concentrations $\left(10^{-5} \mathrm{~mol} / \mathrm{l}\right.$; Fig. 8) the total concentration of aqueous uranium is lower, and the major ionic species between $\mathrm{pH} 6$ and 7.5 would be $\mathrm{UO}_{2} \mathrm{OH}^{+}$rather than $\left(\mathrm{UO}_{2}\right)_{3}(\mathrm{OH})_{5}{ }^{+}$. Figs 7 and 8 , together with Fig. 2, illustrate the pronounced influence of the activity of $\mathrm{UO}_{2}{ }^{2+}$ on hydrolysis in aqueous solution.

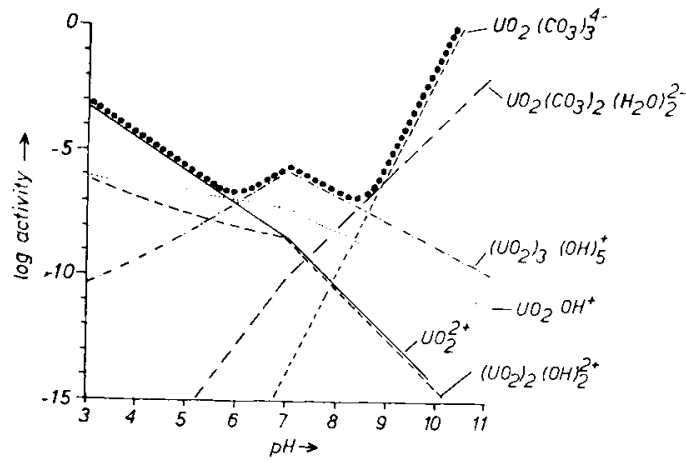

Fig. 7. Activities of uranium species in aqueous solution at a free orthophosphate concentration of $10^{-7} \mathrm{~mol} / \mathrm{l}$ in equilibrium with atmospheric $\mathrm{CO}_{2}$ $(0.03 \% \mathrm{v} / \mathrm{v})$. The activity of total aqueous uranium is indicated by the top dotted line. At $\mathrm{pH}>7$ the activity of $\mathrm{UO}_{2}{ }^{2+}$ is determined by $\mathrm{UO}_{3}$. $\mathrm{H}_{2} \mathrm{O}$ and at $\mathrm{pH}<7$ by $\left(\mathrm{UO}_{2}\right)_{3}\left(\mathrm{PO}_{4}\right)_{2}$. 


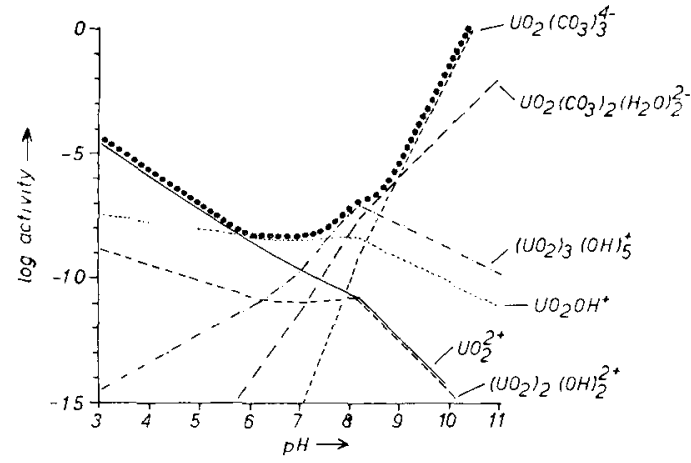

Fig. 8. Activities of uranium species in aqueous solution at a free orthophosphate concentration of $10^{-5} \mathrm{~mol} / 1$ in equilibrium with atmospheric $\mathrm{CO}_{2}$ $(0.03 \% \quad \mathrm{v} / \mathrm{v})$. The activity of total aqueous uranium is indicated by the top dotted line. At $\mathrm{pH}>8$ the activity of $\mathrm{OU}_{2}{ }^{2+}$ is determined by $\mathrm{OU}_{3}$. $\mathrm{H}_{2} \mathrm{O}$ and at $\mathrm{pH}<8$ by $\left(\mathrm{UO}_{2}\right)_{3}\left(\mathrm{PO}_{4}\right)_{2}$.

Fig. 7 shows that the solubility of $\mathrm{U}$ at $\mathrm{pH} 7$ would be about $10^{-8.5} \mathrm{~mol} / \mathrm{l}$ (i.e. of the order of $1 \mu \mathrm{g} / 1$ ) in the presence of a free ortho-phosphate concentration of $10^{-5}$ mol/l. Therefore, the existence of uranium phosphates could explain the occurrence of uranium concentrations of the order of $0.1-10 \mu \mathrm{g} / 1$ in sediment-water systems. The actual free ortho-phosphate concentrations required to maintain aqueous uranium concentrations of the order of $1 \mu \mathrm{g} / \mathrm{l}$ may be higher than $10^{-5} \mathrm{~mol} / \mathrm{l}$, since the effect of other ligands (e.g. organic acids) on the solubility of uranium has not been considered in Figs 7 and 8 . It may be concluded that although uranium phosphates could control uranium solubility in a number of cases, in general the free ortho-phosphate concentrations will not be high enough to maintain uranium concentrations of the order of $1 \mu \mathrm{g} / \mathrm{l}$.

\section{Other ligands}

The actinides, $\mathrm{U}$ and $\mathrm{Th}$ among them, form complexes with halogens and with most oxo anions, such as $\mathrm{NO}_{3}{ }^{-}, \mathrm{SO}_{4}{ }^{2-}, \mathrm{ClO}_{4}{ }^{-}, \mathrm{PO}_{4}{ }^{3-}, \mathrm{HPO}_{4}{ }^{2-}$ and $\mathrm{CO}_{3}{ }^{2-}$ (Cotton \& Wilkinson, 1972).

For uranium, complexes with silicic acid may be of importance too. Silicic acid generally occurs in mineral soils, at concentrations of about $10^{-3} \mathrm{~mol} / 1$ (Wilding et al., 1977). The following reactions describe the dissolution of amorphous silica (50), the dissociation of silicic acid (51), and the complex formation with uranyl (52):

$$
\begin{aligned}
& \mathrm{SiO}_{22} \text { (amorphous) } \rightleftarrows \mathrm{Si}(\mathrm{OH})_{4} \\
& \mathrm{Si}(\mathrm{OH})_{4} \rightleftarrows \mathrm{Si}(\mathrm{OH})_{3} \mathrm{O}^{-}+\mathrm{H}^{+} \\
& \mathrm{UO}_{2}{ }^{2+}+\mathrm{Si}(\mathrm{OH})_{3} \mathrm{O}^{-} \rightleftarrows \mathrm{UO}_{2} \mathrm{Si}(\mathrm{OH})_{3} \mathrm{O}^{+}
\end{aligned}
$$

These reactions yield the following set of equilibrium relationships (Smith \& Martell, 1976):

$$
\begin{aligned}
& \log \left(\mathrm{Si}(\mathrm{OH})_{4}\right)=-2.8 \\
& \log \left(\mathrm{Si}(\mathrm{OH})_{3} \mathrm{O}^{-}\right)=-9.5+\log \left(\mathrm{Si}(\mathrm{OH})_{4}\right)+\mathrm{pH}
\end{aligned}
$$




$$
\log \left(\mathrm{UO}_{2} \mathrm{Si}(\mathrm{OH})_{3} \mathrm{O}^{+}\right)-\log \left(\mathrm{UO}_{2}{ }^{2+}\right)=7.5+\log \left(\mathrm{Si}(\mathrm{OH})_{3} \mathrm{O}^{-}\right)
$$

Inserting Eqs 53 and 54 in Eq. 55, the latter simplifies to:

$$
\log \left(\mathrm{UO}_{2} \mathrm{Si}(\mathrm{OH})_{3} \mathrm{O}^{+}\right)-\log \left(\mathrm{UO}_{2}{ }^{2+}\right)=-4.8+\mathrm{pH}
$$

From Eq. 56 it follows that at $\mathrm{pH} 7$ the uranium-silicate complex dominates $\mathrm{UO}_{2}{ }^{2+}$ by a factor of about 100. It has to be borne in mind, however, that at $\mathrm{pH} 7$ most aqueous uranium will be present as hydrolysis products, such as $\left(\mathrm{UO}_{2}\right)_{3}(\mathrm{OH})_{5}{ }^{+}$, rather than as $\mathrm{UO}_{2}{ }^{2+}$. Assuming that equilibrium exists with respect to $\mathrm{UO}_{3} \cdot \mathrm{H}_{2} \mathrm{O}$ and amorphous $\mathrm{SiO}_{2}$, according to Eqs 29 and 53, respectively, it follows from Eqs 32 and 56 that:

$$
\log \left(\mathrm{UO}_{2} \mathrm{Si}(\mathrm{OH})_{3} \mathrm{O}^{+}\right)-\log \left(\left(\mathrm{UO}_{2}\right)_{3}(\mathrm{OH})_{5}{ }^{+}\right)=-0.4
$$

Therefore, when they are expressed in moles of $U$ per litre, it follows that approximately equal amounts of $U$ in solution are present as complexes with silicate and as hydrolysis products.

Uranium and thorium may form stable complexes with carboxylic acids as well (Martell \& Smith, 1977). Owing to the omnipresence of carboxylic groups in soils, in soil organic matter as well as in humic and fulvic acids, it seems worth-while to pay some attention to complex formation with simple carboxylic acids, such as acetic acid and oxalic acid, in order to assess the effect of complex formation with organic acids on the solubility of uranium and thorium in soils. Acetic acid, $\mathrm{CH}_{3} \mathrm{COOH}$, is an example of a simple monocarboxylic acid, which may serve to illustrate the affinity of uranium and thorium to the carboxylic group. Uranyl and thorium ions form complexes with acetate ions rather than with acetic acid, but at near neutral and higher $\mathrm{pH}$ nearly all of the carboxylic acids occur in dissociated form, such that the acetic acid concentration is approximately equal to the acetate concentration at $\mathrm{pH} 6$ and higher. In order to simplify the notation, $\mathrm{UO}_{2}{ }^{2+}$ is denoted by $\mathrm{M}^{2+}$, $\mathrm{Th}^{4+}$ by $\mathrm{M}^{4+}$ and $\mathrm{CH}_{3} \mathrm{COO}^{-}$by L-, in Figs 9 and 10 .

Fig. 9 shows that at an acetate concentration of $10^{-3} \mathrm{~mol} / 1$ most uranium in solution occurs in positively charged form, whereas at $10^{-2} \mathrm{~mol} / \mathrm{l}$ and higher, most species in solution are uncharged or negatively charged. In particular the negatively charged species, $\mathrm{UO}_{2}\left(\mathrm{CH}_{3} \mathrm{COO}\right)_{3}{ }^{-}$, may be expected to be rather mobile in soil systems. In most soils concentrations of moncarboxylic acids will not be as high as

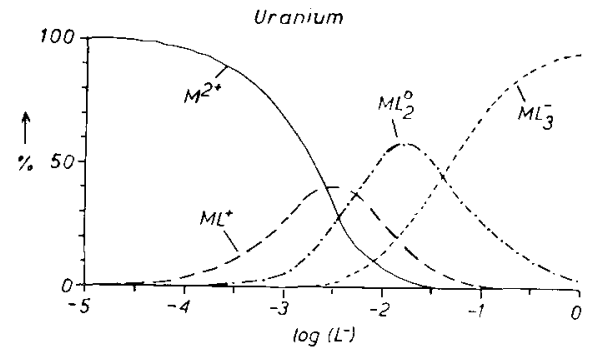

Fig. 9. Fractional occurrence of uranyl ion and uranyl-acetate complexes in aqueous solution, as a function of acetate concentration. 
$10^{-2} \mathrm{~mol} / \mathrm{l}$, but under extreme conditions, such as in or near sanitary landfills, concentrations of $10^{-2} \mathrm{~mol} / \mathrm{l}$ may easily be reached.

Fig. 10 shows that thorium forms even more stable complexes with acetate. It has to be borne in mind, however, that the major uranium and thorium species in aqueous solution in the $\mathrm{pH}$ range of interest are not the simple $\mathrm{UO}_{2}{ }^{2+}$ and $\mathrm{Th}^{4+}$ ions, but rather hydrolysis products of these ions. Therefore, the effect of monocarboxylic acids on the solubility of $U$ and $T h$ in soils cannot simply be derived from Figs. 9 and 10. It may be expected, however, that complex organic acids, such as humic and fulvic acids, do increase the solubility of $\mathrm{U}$ and $\mathrm{Th}$ in soils. It may be noted that these complex organic acids, which contain several functional groups per molecule, may form stronger complexes with $\mathrm{U}$ and $\mathrm{Th}$ than monocarboxylic acids. For example, uranium and thorium form stronger complexes with dicarboxylic acids (oxalic acid, malonic acid) and tricarboxylic acids (citric acid) than with moncarboxylic acids. In particular, thorium forms very stable complexes with oxalic acid, HOOC-COOH. At a concentration of free oxalate of $10^{-8} \mathrm{~mol} / \mathrm{I}$ (i.e. less than $1 \mu \mathrm{g} / 1)$ thorium complexes of the form $\mathrm{ThC}_{2} \mathrm{O}_{4}{ }^{2+}$ and $\mathrm{Th}\left(\mathrm{C}_{2} \mathrm{O}_{4}\right)_{2}{ }^{\circ}$, would dominate $\mathrm{Th}^{4+}$ by a factor of about 10 , whereas at an oxalate concentration of $10^{-6} \mathrm{~mol} / 1$ this factor would be about $10^{5}$. At $\mathrm{pH} 6$, the major thorium species in solution, $\mathrm{Th}(\mathrm{OH})_{2}{ }^{2+}$, would also dominate $\mathrm{Th}^{4+}$ by a factor of about $10^{5}$. Therefore, at $\mathrm{pH} 6$ and a free oxalate concentration of $10^{-6} \mathrm{~mol} / \mathrm{l}$, approximately equal amounts of Th in solution would be present as organic complex and as hydrolysis products.

\section{Adsorption}

Although little information seems to be available about adsorption of $U$ and $T h$ in soils, it may be expected that positively charged uranium and thorium compounds will be strongly adsorbed in soils. Like for other heavy metals, the adsorption will be strongest in the low concentration range (Harmsen, 1977) and will be favoured by a high $\mathrm{pH}$. It has been proposed (James \& Healy, 1972) that hydrolysed species rather than simple heavy metal ions are adsorbed on oxide surfaces. This would in part explain the strong $\mathrm{pH}$ dependence of adsorption of heavy metals in soils, since both hydrolysis and the charge of oxide surfaces depend on $\mathrm{pH}$. The fact that uranium and thorium do occur to a large extent in hydrolyzed form in soil-

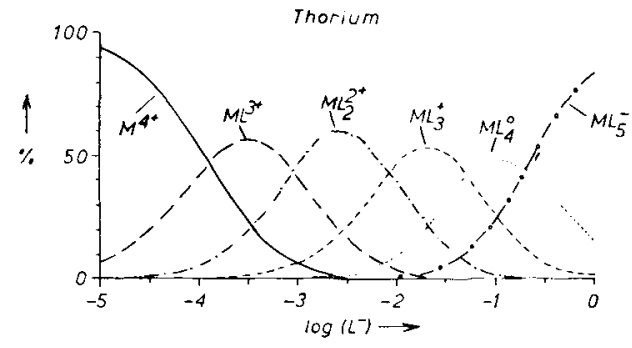

Neth. J. agric. Sci. 28 (1980)
Fig. 10. Fractional occurrence of thorium ion and thorium-acetate complexes in aqueous solution as a function of acetate concentration. 
water systems, together with the high affinity of actinides to oxo-anion groups, in particular the high affinity of $U$ to the silanol group, and the high affinity to carboxylic-acid groups, make it very likely that $U$ and $T h$ will be strongly adsorbed in soils, by both organic and mineral soil constituents.

Uranium concentrations in natural waters are generally in the range $0.1-10 \mu \mathrm{g} / 1$. Fig. 5 shows that the solubility of uranium in equilibrium with $\mathrm{UO}_{3} \cdot \mathrm{H}_{2} \mathrm{O}$ is higher by a factor $10^{2}-10^{3}$. This implies that $\mathrm{UO}_{3} \cdot \mathrm{H}_{2} \mathrm{O}$ cannot be the solid phase determining uranium solubility in water-sediment systems. Precipitation of uranium phosphates could explain the lower solubility of uranium in some cases, but the general occurrence of uranium contents in the range $0.1-10 \mu \mathrm{g} / 1$ would point to a control mechanism such as adsorption to Fe and Mn oxides (Jenne, 1968), to silica and silicates, or to organic matter. Although adsorption of positively charged uranium species would increase with $\mathrm{pH}$, thus lowering the aqueous concentrations of uranium, the relative amount of uncharged and negatively charged uranium species (carbonates, carboxylic acids), which would not be adsorbed, or to a lesser extent, would also increase with $\mathrm{pH}$. These opposing tendencies could explain the fact that uranium contents in natural waters seem to be quite constant over a range of $\mathrm{pH}$ values.

\section{Acknowledgment}

The contributions of Dr F. van Dorp, Institute for Atomic Sciences in Agriculture, Wageningen, the Netherlands, and Mr J. Bothof, Ministry of Public Health and Environmental Hygiene, Leidschendam, the Netherlands, during the initial stages of this study are gratefully acknowledged.

Thanks are due to Dr N. van Breemen, Department of Soil Science and Geology, and Dr W. H. van Riemsdijk, Department of Soils and Fertilizers, both at the Agricultural University, Wageningen, the Netherlands, for critical reading of the manuscript, and to Mr B. W. Matser, Department of Soils and Fertilizers, for drawing the figures.

\section{References}

Baranov, V. I. \& N. G. Morozova, 1971. Behavior of natural radionuclides in soil. Chapter 1 in: Klechkovskii et al. (1971).

Beek, J., 1979. Phosphate retention by soil in relation to waste disposal. Doctoral thesis, Agricultural State University, Wageningen, the Netherlands.

Brits, R. J. N. \& M. C. B. Smit, 1977. Determination of uranium in natural waters by preconcentration on anion-exchange resin and delayed-neutron counting. Analyt. Chem. 49: 67-69.

Burba, P., B. Gleitschmann \& K. H. Lieser, 1978. Abtrennung und Röntgenfluorescenzanalyse von gelösten Uran aus natürlichem Wasser mittels chelatbildender Celluloseaustauscher (am Beispiel natürlicher Wasserproben). Fresenius $Z$. analyt. Chem. 289: 28-34.

Cotton, F. A. \& G. Wilkinson, 1972. Advanced inorganic chemistry, 3rd ed. Interscience, New York. 
Deutscher, R. L. \& A. W. Mann, 1977. Determination of uranium in natural waters by differential-pulse polarography of a trioctylphosphine oxide extract. Analyst. 102: 929-933.

Fleischer, R. L. \& A. C. Delany, 1976. Determination of suspended and dissolved uranium in water, Analyt. Chem. 48: 642-645.

Garrels, R. M. \& C. L. Christ, 1965. Solutions, minerals, and equilibria. Freeman, Cooper \& Comp., San Francisco.

Gladney, E. S., J. W. Owens \& J. W. Starner, 1976. Determination of uranium in natural waters by neutron activation analysis. Analyt. Chem. 48: 973-975.

Goldberg, E. D., 1975. Minor elements in sea water. Chapter 5 in: Riley \& Skirrow (1975).

Harmsen, K., 1977. Behaviour of heavy metals in soils. Agric. Res. Rep. 866. Pudoc, Wageningen, the Netherlands.

Hathaway, L. R. \& G. W. James, 1975. Use of chelating ion-exchange resin in the determination of uranium in ground water by X-ray fluorescence. Analyt. Chem. 47: 2035-37.

ICRP, 1959. Radiation protection. Recommendations of the International Commission on Radiological Protection. ICRP Publication 2. Pergamon Press, New York.

ICRP, 1964. Radiation protection. Recommendations of the International Commission on Radiological Protection. ICRP Publication 6. Pergamon Press, Oxford.

James, R. O. \& T. W. Healy, 1972. Adsorption of hydrolyzable metal ions at the oxide-water interface. III. A thermodynamic model of adsorption. J. Colloid Interface Sci. 40: 65-81.

Jenne, E. A., 1968. Controls on $\mathrm{Mn}, \mathrm{Fe}, \mathrm{Co}, \mathrm{Ni}, \mathrm{Cu}$, and $\mathrm{Zn}$ concentrations in soils and water: the significant role of hydrous Mn and Fe oxides. Adv. Chem. Ser. 73: 337-387.

Kahlos, H. \& M. Asikainen, 1973. Natural radioactivity of ground water in the Helsinki area. Report SFL-A19, Institute of Radiation Physics, Helsinki, Finland.

Klechkovskii, V. M., G. G. Polikarpov \& R. M. Aleksakhin (Ed.), 1971. Radioecology. Translated from Russian by Israel Program for Scientific Translations, 1973. A Halsted Press Book. Wiley, New York.

Klein, D. H., A. W. Andren, J. A. Carter, J. F. Emery, C. Feldman, W. Fulkerson, W. S. Lyon, J. C. Ogle, Y. Talmi, R. I. Van Hook \& N. Bolton, 1975. Pathways of thirty-seven trace elements through coal-fired power plant. Envir. Sci. Technol. 9: 973-979.

Klement, A. W., 1965. Natural radionuclides in foods and food source materials. In: E. B. Fowler (Ed.), Radioactive fallout, soils, plants, foods, man, Ch. 6, Elsevier, Amsterdam.

Korkisch, J. \& D. Dimitriadis, 1973. Anwendung von ionenaustauschverfahren zur Bestimmung von Spurenelementen in natürlichen Wässern. III. Thoriun. Talanta 20: 1303-8.

Korkisch, J. \& L. Gödl, 1974. Determination of uranium in natural waters after anion-exchange separation. Analyt. chim. Acta 71: 113-121.

Lindsay, W. L., 1972. Inorganic phase equilibria of micronutrients in soils. In: J. J. Mortvedt, P. M. Giordano \& W. L. Lindsay (Eds.), Micronutrients in agriculture, Ch. 3. Soil Science Society of America, Madison, Wisc.

Martell, A. E. \& R. M. Smith, 1977. Critical stability constants. Volume 3: Other organic ligands. Plenum Press, New York.

Menzel, R. G., 1968. Uranium, radium, and thorium content in phosphate rocks and their possible radiation hazard. J. Agric. Food Chem. 16: 231-234.

Mitchell, R. L., 1955. Trace elements. In: F. E. Bear (Ed.), Chemistry of the soil, Ch. 9. Reinhold, New York.

Moffet, D. \& M. Tellier, 1978. Radiological investigations of an abandoned uranium tailings area. J. Envir. Qual. 7: 310-14.

Osburn, W. S., 1965. Primordial radionuclides: Their distribution, movement, and possible effect within terrestrial ecosystems. Health Phys. 11: 1275-95.

Pourbaix, M., 1963. Atlas d'equilibres électrochimiques. Gauthier-Villars, Paris.

Riley, J. P. \& G. Skirrow (Eds.), 1975. Chemical oceanography. Academic Press, New York.

Robie, R. A., B. S. Hemingway \& J. R. Fischer, 1978. Thermodynamic properties of minerals and related substances at $298.15 \mathrm{~K}$ and $1 \mathrm{Bar}\left(10^{5}\right.$ Pascals $)$ pressure and at higher temperatures. U.S. Geol. Surv. Bull. 1452. U.S. Government Printing Office, Washington.

Scott, R. C. \& F. B. Barker, 1962. Data on uranium and radium in ground water in the United States 1954-1957. Geol. Surv. Prof. Paper 426. U.S. Government Printing Office, Washington. 


\section{K. HARMSEN AND F. A. M. DE HAAN}

Sloot, H. A. van der, 1976. Neutron activation analysis of trace elements in water samples after preconcentration on activated carbon. Report ECN-1. Netherlands Energy Research Foundation, Petten, the Netherlands.

Sloot, H. A. van der, 1979. Activated carbon as a means of concentration for trace elements. (In Dutch.) Chem. Weekbl. 1979: 297-299.

Smith, R. M. \& A. E. Martell, 1976. Critical stability constants, Volume 4: Inorganic complexes. Plenum Press, New York.

Stumm, W. \& J. J. Morgan, 1970. Aquatic chemistry. Wiley-Interscience, New York.

Sugimura, Y., T. Torii \& S. Murata, 1964. Uranium distribution in Drake Passage Waters. Nature 204: 464-5.

Talibudeen, O., 1964. Natural radioactivity in soils. Soils Fert. 27: 347-59.

UNSCEAR, 1977. Sources and effects of ionizing radiation. U.N. Scientific Committee on Effects of Atomic Radiation, 1977; report to the General Assembly, with annexes. U.N. Publ., E. 77.IX.1., U.N., New York.

Vinogradov, A. P., 1959. The geochemistry of rare and dispersed chemical elements in soils. Consultants Bureau, New York.

Walker, F. W., G. J. Kirouac \& F. M. Rourke, 1977. Chart of the nuclides, 12th ed. Knolls Atomic Power Laboratory, Schenectady, New York/General Electric Cy, San Jose, California.

Weast, R. C. (Editor-in-Chief), 1973. Handbook of chemistry and physics, 53rd ed. Chemical Rubbe Cy, Cleveland, Ohio.

Wilding, L. P., N. E. Smeck \& L. R. Drees, 1977. Silica in soils: quartz, cristobalite, tridymite, and opal. In: J. B. Dixon \& S. B. Weed (Eds.), Minerals in soil environments, Ch. 14. Soil Science Society of America, Madison, Wisc. 